\title{
Performance of Class F Pulverised Fuel Ash and Ground Granulated Blast Furnace Slag in Ternary Concrete Mixes
}

\author{
Jhon Kamau, Ash Ahmed, Paul Hirst, and Joseph Kangwa
}

\begin{abstract}
Cement is the most utilised material after water, and the processes that are involved in making it are energy intensive, contributing to about $7 \%$ of the total global anthropogenic carbon dioxide $\left(\mathrm{CO}_{2}\right)$. Energy efficiency can however be achieved by using Supplementary Cementitious Materials (SCMs) such as Pulverised Fuel Ash (PFA) and Ground Granulated Blast Furnace Slag (GGBS) which demand less process heating and emit fewer levels of $\mathrm{CO}_{2}$. This work examined the advantages of substituting cement using PFA and GGBS in ternary (2 SCMs) concrete at steps of $0 \%, 5 \%, 7.5 \%$, $10 \%, 15 \%, 20 \%, 25 \%$, and $30 \%$. It was found that PFA increased the workability of GGBS, whereas GGBS improved the strength of PFA. The densities of the resultant concrete were below those of the $0 \%$ replacement as well as those of individual binary (1 SCM) concretes. The tensile strengths of the ternary concrete were lower than those of the binary concretes, whereas the gains in compressive strengths over curing time were higher at lower replacements for the ternary concrete compared with the $0 \%$ replacement and the binary concretes, but lower at higher replacements. The findings indicate that PFA and GGBS could be used together to improve the properties of concrete where each falls short.
\end{abstract}

Index Terms-Ternary concrete; GGBS; PFA.

\section{INTRODUCTION}

It has been argued that cement is one of the most notorious contributors to global anthropogenic $\mathrm{CO}_{2}$ [1]. Being the main ingredient in concrete, it has been described as the most utilised construction material in the world, its global consumption only seconding that of water [2], [3]. It accounts for about $7 \%$ of the total global $\mathrm{CO}_{2}$ loading in the atmosphere [2]. Accordingly, it appears that the global emissions which result from its production could be higher than those associated with aviation, which were only estimated at $2 \%$ by [4]. More so, it has also been claimed that the production of a tonne of cement emits approximately a corresponding tonne of $\mathrm{CO}_{2}$, making it the most energyintensive material produced after steel and aluminium [2].

There is growing consensus in literature that the use of Supplementary Cementitious Materials (SCMs) in concrete mixes under optimum conditions of blending, transportation, placing and curing improves the strength and durability of hardened concrete, with researchers agreeing on replacements of up to 35\% for Pulverised Fuel Ash (PFA) and $65 \%$ for Ground Granulated Blast Furnace Slag [GGBS] [5].

The use of SCMs helps in preserving the environment by adding sustainability to concrete through the reduction of $\mathrm{CO}_{2}$ that is emitted during the production of cement, reducing on the amount of cement consumed by increasing the volume of mixes due to their lower particle specific gravity, mitigating on the pollution of land that results from landfill dumping and improving the properties of both fresh and hardened concrete, thereby enhancing the service life of structures [5]. Their use also leads to economic benefits, as most of them are industrial by products [2].

SCMs are defined by [6] as materials that are used in concrete in addition to cement, and consist of mainly reactive silicon dioxide $\left(\mathrm{SiO}_{2}\right)$ or glass, and aluminium oxide $\left(\mathrm{Al}_{2} \mathrm{O}_{3}\right)$, with the remainder being iron oxide $\left(\mathrm{Fe}_{2} \mathrm{O}_{3}\right)$ and other oxides such as magnesium $(\mathrm{MgO})$ and calcium oxide $(\mathrm{CaO})[6] . \mathrm{CaO}$ is essential for early strength development, whereas $\mathrm{SiO}_{2}$ and $\mathrm{Al}_{2} \mathrm{O}_{3}$ are vital for latter age strength development, also known as the secondary hydration phase [5].

The latter age strength that is associated with SCMs is due to the reaction of $\mathrm{SiO}_{2}$ with free lime $\left[\mathrm{Ca}(\mathrm{OH})_{2}\right]$ from the hydration of cement through the secondary reaction over time to form strength giving compounds such as Calcium Silicate Hydrate (C-S-H) which are less permeable and less dense [5], [7].

According to [8], SCMs can be used either independently or combined with others to form either binary (1 SCM) or ternary (2 SCM) mixes due to their abundant availability.

PFA is defined by [6] as a fine residual material that results from the burning of ground and pulverised coal by power plants. Pozzolanic PFA consisting of mainly $\mathrm{SiO}_{2}$ and $\mathrm{Al}_{2} \mathrm{O}_{3}$, with other compounds contained in smaller proportions is grouped as class F [6]. American Society for Testing and Materials [9] and [6]'s recommendations on PFA class F are that the chemical composition should constitute of a sum of at least $70 \% \mathrm{SiO}_{2}, \mathrm{Al}_{2} \mathrm{O}_{3}$ and $\mathrm{Fe}_{2} \mathrm{O}_{3}$.

Ground Granulated Blast Furnace Slag (GGBS) on the other hand is a by-product of pig iron manufacture in a blast furnace at temperatures of about $1500^{\circ} \mathrm{C}$, and consists of mainly calcium silicates and other bases [6]. GGBS possesses

Published on June 20, 2017

J. Kamau is with the Civil Engineering Group. Leeds Beckett University, Leeds, England, UK (email: John.kamau@yahoo.com)

A. Ahmed is with the Civil Engineering Group. Leeds Beckett University, Leeds, UK (email: A.R.Ahmed@leedsbeckett.ac.uk)

P. Hirst is with the Civil Engineering Group. Leeds Beckett University, Leeds, England, UK (email: P.Hirst@leedsbeckett.ac.uk)

J. Kangwa was with the Civil Engineering Group. Leeds Becket University, Leeds, England, UK. He is now with London South Bank University, London, England, UK (email: kangwaj2@1sbu.ac.uk) 
hydraulic properties when it is suitably activated as it contains large volumes of $\mathrm{CaO}$ [5], [6]. The requirements of [6] are that GGBS should contain at least two thirds of the sum of $\mathrm{CaO}, \mathrm{MgO}$ and $\mathrm{SiO}_{2}$ by mass, with the remainder being $\mathrm{Al}_{2} \mathrm{O}_{3}$ and other compounds in small quantities [6]. The ratio of $(\mathrm{MgO}+\mathrm{CaO})$ to $\mathrm{SiO}_{2}$ must exceed $1[6]$.

\section{RESEARCH SIGNIFICANCE}

It has been reported that the use of ternary or quaternary (3 SCMs) in a concrete mix helps to complement properties where individual SCMs fall short [5], [10]. Sathawane et al [10] reported that Rice Husk Ash (RHA) significantly improved the compressive strength of PFA at latter ages due to its higher amorphous silica content and the high pozzolanic activity that is associated with it, whereas due to its low binding property, PFA improved the workability of RHA. Bapat [5] on the other hand reported that the use of PFA and GGBS together significantly increased the compressive strength of concrete at all ages.

Nehdi, et al. [11] reported that ternary PFA and GGBSreplaced concrete achieved higher compressive strengths than the binary PFA-replaced specimens. Sathawane, et al. [10] however reported that the addition of RHA to PFA concrete reduced tensile strengths of the resultant ternary concrete.

No work was found on the performance of ternary PFA and GGBS on workability, density, and increase in compressive strength over curing age. Moreover, with a decline in coal production in the UK due the shutting down of old polluting coal-power stations and closure of coal mines [12], there will be a need to optimise on PFA as it eventually becomes scarce, and using it in ternary mixes alongside GGBS could be one of the solutions. This research focused on the performance of PFA and GGBS ternary mixes on workability, density, compressive and tensile strengths and gain in compressive strength over time.

\section{METHODS}

Cement was replaced in concrete at the point of need using $50 \%$ GGBS and 50\% PFA by weight at steps of $0 \%, 5 \%$, $7.5 \%, 10 \%, 15 \%, 20 \%, 25 \%$ and $30 \%$. The $0 \%$ replacement, also refered to as the control was the reference from which all performances were measured [13]. Binary specimens of PFA and GGBS were also cast at the same levels of replacements and were used as extra points of reference.

Concrete mixing conformed to [14]. The quantities of cement, fine aggregates, coarse aggregates and water were $380 \mathrm{~kg}, 760 \mathrm{~kg}, 1140 \mathrm{~kg}$ and 180 liters per cubic meter respectively or a mix proportion of 1: 2: 3 . Aggregates, cement and water were introduced into a concrete mixer, which was run for a total of eight minutes with a three-minute rest in between the mixing. A constant Water Cement Ratio (WCR) of 0.5 with no superplasticisers was used for all mixes in a bid to achieve a good balance of workability and strength in line with Abram's law, which states that the strength of a concrete mix is determined by the WCR, with lower WCRs spelling higher strengths and vice-versa [15]. As a result, 0.5 was settled upon as [16] reported it as the minimum WCR that was required to make cement mortar workable.

Workability was assessed using the slump test to [17]. The apparatus were a slump cone, tamping rod and steel floater.
The slump mould was filled in three layers and compacted using 25 uniform, vertical strokes of the tamping rod for each layer, which were distributed evenly across the surface. The top of the mould was then levelled using the steel floater, and the mould carefully removed. Slump was determined by measuring the difference between the top of the mould and the highest point of the slumped specimen.

The cube moulds used to make cube specimens for compressive strengths measured $100 \mathrm{~mm}$ x $100 \mathrm{~mm}$ x 100 $\mathrm{mm}$, whereas cylinder moulds used to make cylindrical specimens for splitting tensile strengths were $150 \mathrm{~mm}$ in diameter and $300 \mathrm{~mm}$ in height conforming to dimension guidelines of [18].

The cube and cylinder specimens were cast conforming to [19]. The insides of the moulds were sprayed with a thin film of non-reactive release material. The cube moulds were then filled with concrete and firmly secured on to a mechanical vibrating table to commence the compaction process.

For cylinders, three equal layers with 25 uniform, vertical strokes of the tamping rod, distributed equally on the whole surface of each layer were used. The cubes and cylinders were left in the moulds for 24 hours, after which they were stripped, marked and submerged in a water tank at temperatures of $20^{\circ} \mathrm{C}$, and a $\mathrm{pH}$ of 7 until their age of testing conforming to [19].

Specimens were cured for up to 91 days following the rationale that pozzolanic reactions require the hydration products of cement in the presence of water for the secondary hydration to take place and form further calcium silicate and calcium aluminate compounds, which are strength giving and less permeable [5].

To work out density, cubes were weighed in air and while submerged in water. Density was then calculated using (1) [20]

$$
\mathrm{D}=\frac{\text { Mass }}{\text { Volume }}
$$

Compressive strength tests were carried out conforming to [21]. The cubes were applied perpendicularly in the direction of the casting. A load of $0.6 \mathrm{~N} / \mathrm{mm}^{2}$.s was applied. After this application of the initial load, which according to [21] does not exceed approximately $30 \%$ of the failure load, further constant load was applied at a rate of $\pm 10 \%$ until no further load could be sustained. Compressive tests were carried out at $7,28,56$, and 91 days.

The compressive strength results were expressed in $\mathrm{N} / \mathrm{mm}^{2}$, and were a mean of three identical specimens to ensure repeatability [21].

Tensile strengths were conducted conforming to [22]. The test specimens were placed centrally in the machine and packing strips carefully positioned with the upper and lower platens parallel to each other. Initial load was applied at a constant rate of stress of $0.04 \mathrm{~N} / \mathrm{mm}^{2}$.s, which, according to [22] does not exceed $20 \%$ of the failure load. Further constant load was thereafter applied at a rate of $\pm 10 \%$ until no further load could be sustained. The splitting tensile strength was calculated using (2) conforming to [22].

$\mathrm{f}_{\mathrm{ct}}=\frac{2 \times \mathrm{F}}{\pi \mathrm{Lxd}}$ 


\section{RESULTS AND DISCUSSION}

Table I shows the chemical composition of PFA and GGBS used for this study, which was obtained from X-Ray diffraction (XRD). PFA conformed to [6]. [9] and [6]'s specifications of a combination of at least $70 \% \mathrm{SiO}_{2}, \mathrm{Al}_{2} \mathrm{O}_{3}$ and $\mathrm{Fe}_{2} \mathrm{O}_{3}$ for PFA class $\mathrm{F}$.

GGBS contained more than two thirds of the sum of $\mathrm{CaO}$, $\mathrm{MgO}$ and $\mathrm{SiO}_{2}$ by mass and had a ratio of $(\mathrm{MgO}+\mathrm{CaO})$ to $\mathrm{SiO}_{2}$ that was greater than 1 conforming to [6].

TABle I. Percentage Chemical COMPOSITION OF PFA Class F AND GGBS

\begin{tabular}{lcc}
\hline \hline \multirow{2}{*}{ Chemical } & \multicolumn{2}{c}{ Percentage Composition } \\
\cline { 2 - 3 } & Class F PFA & GGBS \\
\hline Silicon dioxide $\left(\mathrm{SiO}_{2}\right)$ & 54.2 & 35.7 \\
\hline Aluminium oxide $\left(\mathrm{Al}_{2} \mathrm{O}_{3}\right)$ & 23.7 & 13.9 \\
\hline Iron oxide $\left(\mathrm{Fe}_{2} \mathrm{O}_{3}\right)$ & 7.3 & 0.3 \\
\hline Calcium oxide $(\mathrm{CaO})$ & 3.1 & 41.2 \\
\hline Magnesium oxide $(\mathrm{MgO})$ & 2.5 & 8.1 \\
\hline Sodium oxide $\left(\mathrm{Na}_{2} \mathrm{O}\right)$ & 0.6 & 0.4 \\
\hline Potassium oxide $\left(\mathrm{K}_{2} \mathrm{O}\right)$ & 4 & 0.4 \\
\hline Loss on ignition $(\mathrm{LOI})$ & 0.4 & 0.7 \\
\hline Sulphur trioxide $\left(\mathrm{SO}_{3}\right)$ & 0.5 & 3.6 \\
\hline \hline
\end{tabular}

\section{A. Workability}

Table II and Fig. 1 show the workability of binary and ternary PFA and GGBS-replaced mixes. The slumps achieved by the ternary mix were of slump classes 1 and 2 from Table 3 of [23].

The slumps of the ternary mix were higher than those of binary PFA-replaced mixes for up to the $7.5 \%$ replacement, but higher than binary GGBS-replaced mixes for all replacements.

The findings confirmed the assumptions of [24] and [10] that SCMs used together in concrete have a complimentary effect on each other because for higher replacements, the high workability of PFA was observed to improve that of GGBS.

TABLE II. SLUMPS OF BINARY AND TERNARY PFA AND GGBS-REPLACED MIXES (MM)

\begin{tabular}{ccccccccc}
\hline \hline & \multicolumn{8}{c}{ Slumps at percentage replacements $(\mathrm{mm})$} \\
\cline { 2 - 10 } & $0 \%$ & $5 \%$ & $7.5 \%$ & $10 \%$ & $15 \%$ & $20 \%$ & $25 \%$ & $30 \%$ \\
\hline PFA & 30 & 20 & 50 & 75 & 130 & 130 & 100 & 90 \\
\hline GGBS & 30 & 10 & 10 & 10 & 10 & 20 & 30 & 30 \\
\hline Ternary & 30 & 40 & 60 & 70 & 75 & 60 & 60 & 70 \\
\hline \hline
\end{tabular}

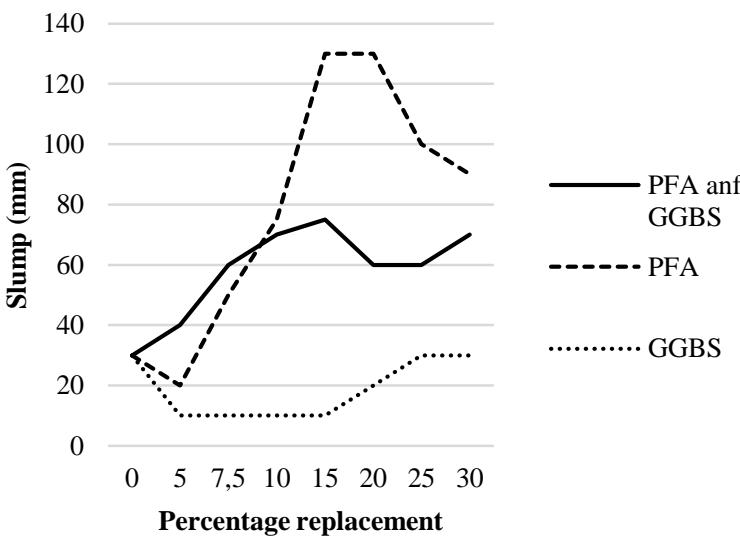

Fig. 1. Slumps of binary and ternary PFA and GGBS-replaced mixes against percentage replacements $(\mathrm{mm})$

\section{B. Densities}

Table III and Fig. 2 show densities of the ternary 50\% PFA and 50\% GGBS-replaced specimens. The densities at all replacement levels remained below those of the control, and decreased with increased replacement, consistent with literature that SCMs have a lower particle specific gravity than that of cement, and for this reason they provide an advantage by reducing the mass of concrete per unit volume [5].

Densities decreased between 28 and 91 days, also consistent with literature that at latter ages, the consumption of $\mathrm{Ca}(\mathrm{OH})_{2}$ during secondary hydration to form the less dense $\mathrm{C}-\mathrm{S}-\mathrm{H}$ decreases the density of specimens [5].

From Table IV and Fig. 2, the densities of the ternary concrete remained below those of PFA-replaced specimens at all replacements, and below those of GGBS-replaced specimens except at the $25 \%$ and $30 \%$ replacements.

The reduction in density of the ternary concrete at 91 days can be attributed to GGBS further reacting with PFA to form more of the less dense C-S-H through the consumption of $\mathrm{Ca}(\mathrm{OH})_{2}[5]$

TABLE III. DENSITIES OF TERNARY PFA AND GGBS-REPLACED SPECIMENS OVER 91 DAYS OF CURING $\left(\mathrm{KG} / \mathrm{M}^{3}\right)$

\begin{tabular}{ccccccccc}
\hline \hline \multirow{2}{*}{$\begin{array}{c}\text { Age } \\
\text { (days) }\end{array}$} & $0 \%$ & $5 \%$ & $7.5 \%$ & $10 \%$ & $15 \%$ & $20 \%$ & $25 \%$ & $30 \%$ \\
\cline { 2 - 8 } & $0 \%$ & 2296 & 2295 & 2291 & 2286 & 2280 \\
\hline 7 & 2350 & 2320 & 2299 & 2296 & 2296 & 2286 & 2290 & 2283 \\
\hline 28 & 2350 & 2319 & 2281 & 2296 & 2293 & 2273 \\
\hline 56 & 2356 & 2312 & 2286 & 2292 & 2285 & 2283 & 2278 & 2273 \\
\hline 91 & 2366 & 2306 & 2284 & 2280 & 2278 & 2273 & 2273 & 2270 \\
\hline \hline
\end{tabular}

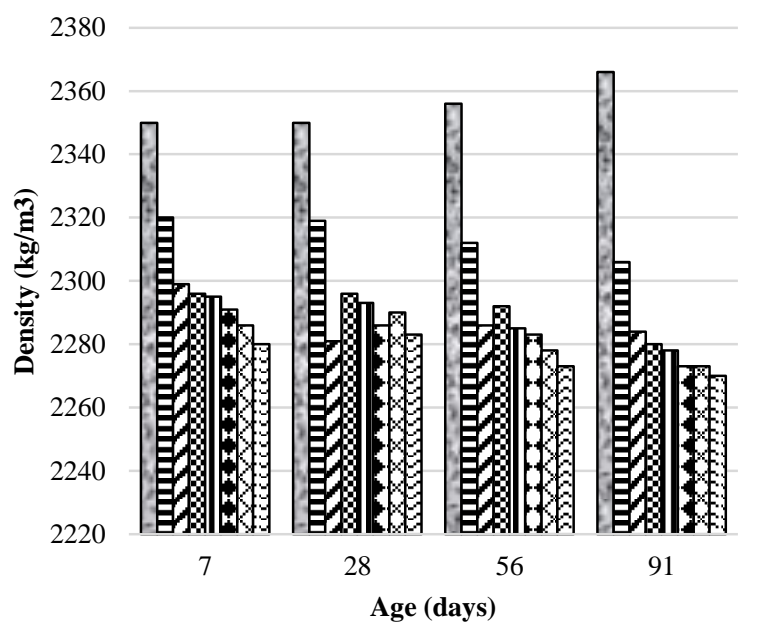

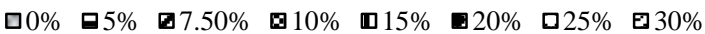

Fig. 2. Densities of ternary PFA and GGBS-replaced specimens against curing age $\left(\mathrm{kg} / \mathrm{m}^{3}\right)$

TABLE IV. DENSITIES OF BINARY AND TERNARY PFA AND GGBSREPLACED SPECIMENS AT 91 DAYS (KG/M3)

\begin{tabular}{ccccccccc}
\hline \multicolumn{1}{c}{ REPLACED SPECIMENS AT 91 DAYS (KG/M3) } \\
\cline { 2 - 9 } & $0 \%$ & $5 \%$ & $7.5 \%$ & $10 \%$ & $15 \%$ & $20 \%$ & $25 \%$ & $30 \%$ \\
\hline PFA & 2366 & 2337 & 2334 & 2330 & 2323 & 2318 & 2299 & 2289 \\
\hline GGBS & 2366 & 2310 & 2301 & 2290 & 2283 & 2274 & 2270 & 2268 \\
\hline Ternary & 2366 & 2306 & 2284 & 2280 & 2278 & 2273 & 2273 & 2270 \\
\hline \hline
\end{tabular}




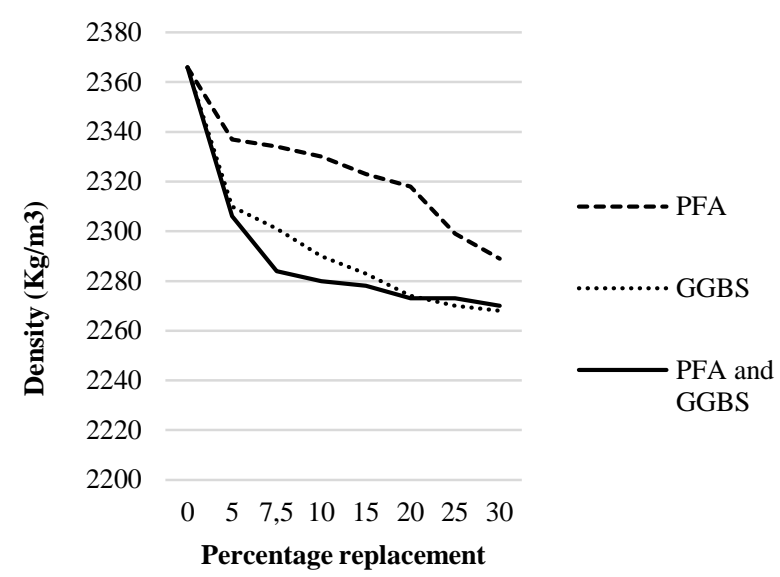

Fig. 3. Densities of binary and ternary PFA and GGBS-replaced specimens at 91 days against percentage replacements $\left(\mathrm{kg} / \mathrm{m}^{3}\right)$

\section{Compressive strength}

Table V and Fig. 4 show the compressive strengths of concrete specimens made from the ternary mix of PFA and GGBS. The compressive strengths were higher than those of the binary PFA-replaced specimens for all replacement levels at 91 days, and lower than those of the binary GGBS-replaced specimens.

The compressive strengths achieved were among the strength classes that are listed by [25] as being durable and suitable for structural applications.

TABLE V. COMPRESSIVE STRENGTHS OF TERNARY PFA AND GGBSREPLACED SPECIMENS (N/MM $\left.{ }^{2}\right)$

\begin{tabular}{ccccccccc}
\hline \hline \multirow{2}{*}{$\begin{array}{c}\text { Age } \\
\text { (days) }\end{array}$} & \multicolumn{6}{c}{ Compressive strengths at percentage replacements $\left(\mathrm{N} / \mathrm{mm}^{2}\right)$} \\
\cline { 2 - 9 } & $0 \%$ & $5 \%$ & $7.5 \%$ & $10 \%$ & $15 \%$ & $20 \%$ & $25 \%$ & $30 \%$ \\
\hline 7 & 56.2 & 42.4 & 39.8 & 41.8 & 34.8 & 41.4 & 33.5 & 34.9 \\
\hline 28 & 61.6 & 47.3 & 46.4 & 47.7 & 49.8 & 48.6 & 46.5 & 46.1 \\
\hline 56 & 67.6 & 51.9 & 50.3 & 49.9 & 49.4 & 49.2 & 48.4 & 47.3 \\
\hline 91 & 71.3 & 56.8 & 61.8 & 61.2 & 60.7 & 57.3 & 53.5 & 52.7 \\
\hline \hline
\end{tabular}

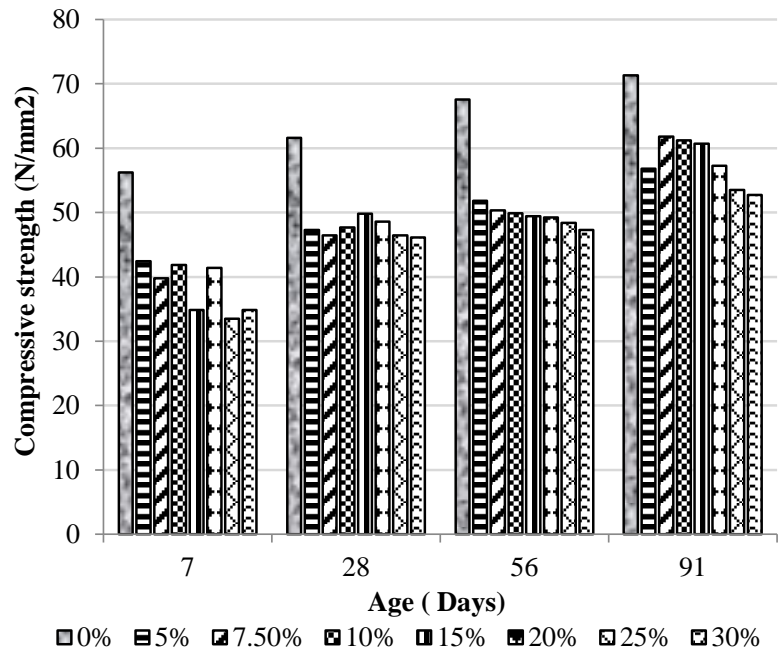

Fig. 4. Compressive strengths of ternary PFA and GGBS-replaced specimens against curing age $(\mathrm{N} / \mathrm{mm} 2)$

Table VI and Fig. 5 show the compressive strengths of binary and ternary PFA and GGBS-replaced specimens at 28 days, whereas Table VII and Fig. 6 show the same information at 91 days. Consistent with [5], the ternary specimens showed higher compressive strengths than those of the binary concrete of PFA at 91 days, leading to a conclusion that GGBS might have reacted with PFA at latter ages to form further cementitious products [5].

GGBS was observed to improve the strength performance of PFA throughout all replacements at 91 days, also consistent with literature that SCMs have a complimentary effect on each other when used in ternary mixes, especially because PFA was also observed to improve the workability of GGBS [5].

The results also confirmed [11]'s findings, that ternary PFA and GGBS-replaced concrete achieved higher compressive strengths than the binary PFA-replaced specimens. Elsewhere, [10] reported that RHA significantly improved the compressive strength of PFA at latter ages due to its higher amorphous silica content and pozzolanic activity.

TABLE VI. COMPRESSIVE STRENGTHS OF BINARY AND TERNARY PFA AND GGBS-REPLACED SPECIMENS AT 28 DAYS (N/MM²)

\begin{tabular}{lcccccccc}
\hline \hline & \multicolumn{7}{c}{ Compressive strengths at percentage replacements $\left(\mathrm{N} / \mathrm{mm}^{2}\right)$} \\
\cline { 2 - 10 } & $0 \%$ & $5 \%$ & $7.5 \%$ & $10 \%$ & $15 \%$ & $20 \%$ & $25 \%$ & $30 \%$ \\
\hline PFA & 61.6 & 48.9 & 47.1 & 42.7 & 43.1 & 38.4 & 38.2 & 40.5 \\
\hline GGBS & 61.6 & 45.6 & 46.7 & 47.2 & 46.8 & 46.6 & 46 & 45.4 \\
\hline Ternary & 61.6 & 47.3 & 46.4 & 47.7 & 49.8 & 48.6 & 46.5 & 46.1 \\
\hline \hline
\end{tabular}

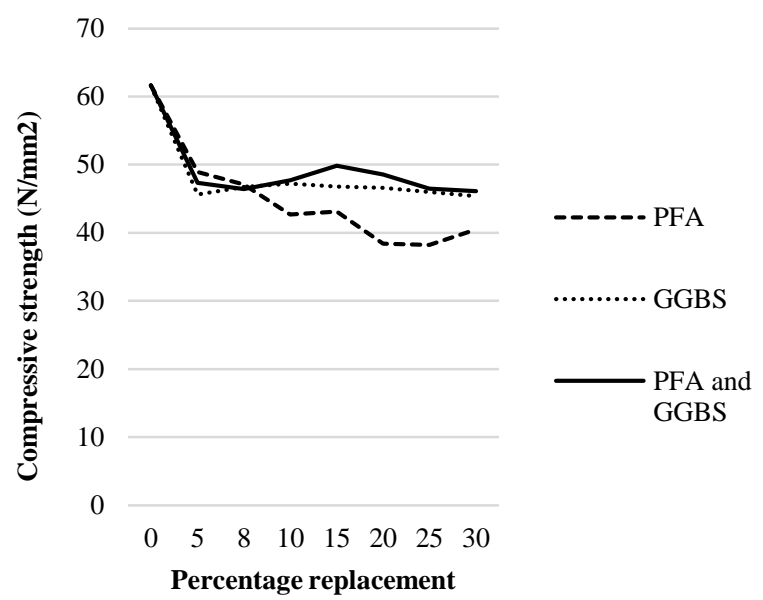

Fig. 5. Compressive strengths of binary and ternary PFA and GGBSreplaced specimens against percentage replacements at 28 days $\left(\mathrm{N} / \mathrm{mm}^{2}\right)$

TABLE VII. COMPRESSIVE STRENGTHS OF BINARY AND TERNARY PFA AND GGBS-REPLACED SPECIMENS AT 91 DAYS $\left(\mathrm{N} / \mathrm{MM}^{2}\right)$

\begin{tabular}{ccccccccc}
\hline \multicolumn{7}{c}{ Compressive strengths at percentage replacements $\left(\mathrm{N} / \mathrm{mm}^{2}\right)$} \\
\cline { 2 - 9 } & $0 \%$ & $5 \%$ & $7.5 \%$ & $10 \%$ & $15 \%$ & $20 \%$ & $25 \%$ & $30 \%$ \\
\hline PFA & 71.3 & 56.7 & 55.9 & 51.0 & 54.0 & 48.7 & 50.7 & 50.5 \\
\hline GGBS & 71.3 & 53.1 & 60.3 & 61.8 & 62.6 & 61.2 & 60.7 & 54.1 \\
\hline Ternary & 71.3 & 56.8 & 61.8 & 61.2 & 60.7 & 57.3 & 53.5 & 52.7 \\
\hline \hline
\end{tabular}




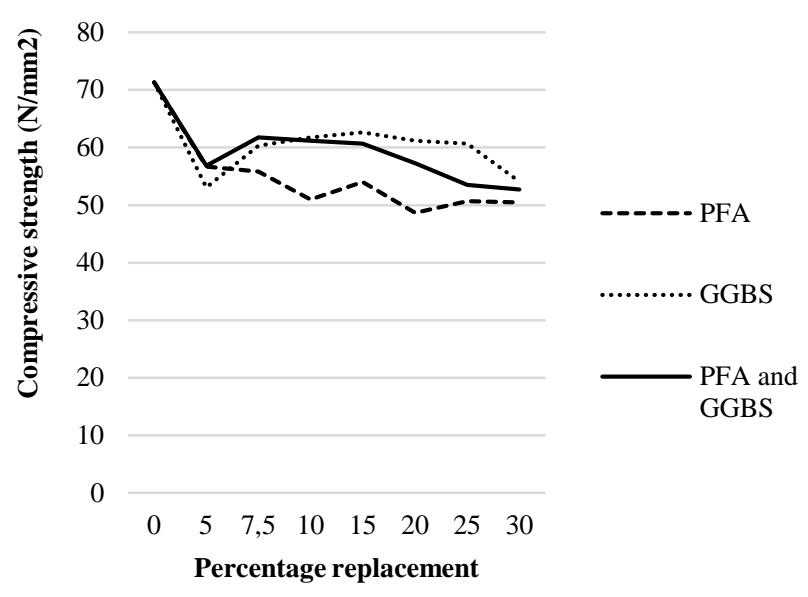

Fig. 6. Compressive strengths of binary and ternary PFA and GGBSreplaced specimens at 91 days against percentage replacements $\left(\mathrm{N} / \mathrm{mm}^{2}\right)$

\section{Tensile strengths}

Table VIII and Fig. 7 show the tensile strengths achieved by the binary and ternary PFA and GGBS-replaced specimens at 91 days. Unlike the compressive strengths, the splitting tensile strengths were consistently lower than those of individual binary specimens, and decreased with increased replacement.

These findings were consistent with [10] who reported that the addition of RHA to PFA concrete reduced tensile strengths of the resultant ternary concrete.

TABLE VIII. TENSILE STRENGTHS OF BINARY AND TERNARY PFA AND GGBS-REPLACED SPECIMENS AT 91 DAYS (N/MM $\left.{ }^{2}\right)$

\begin{tabular}{cccccccccc}
\hline \multicolumn{7}{c}{ GGBS-REPLACED SPECIMENS AT 91 DAYS (N/MM $)$} \\
\cline { 2 - 9 } & $0 \%$ & $5 \%$ & $7.5 \%$ & $10 \%$ & $15 \%$ & $20 \%$ & $25 \%$ & $30 \%$ \\
\hline PFA & 3.6 & 4.1 & 3.9 & 3.5 & 3.3 & 3.2 & 2.9 & 2.8 \\
\hline GGBS & 3.6 & 3.9 & 3.5 & 4.1 & 3.5 & 3.7 & 3.5 & 2.8 \\
\hline Ternary & 3.6 & 3.1 & 3.1 & 2.6 & 3 & 2.8 & 2.6 & 2.3 \\
\hline \hline
\end{tabular}

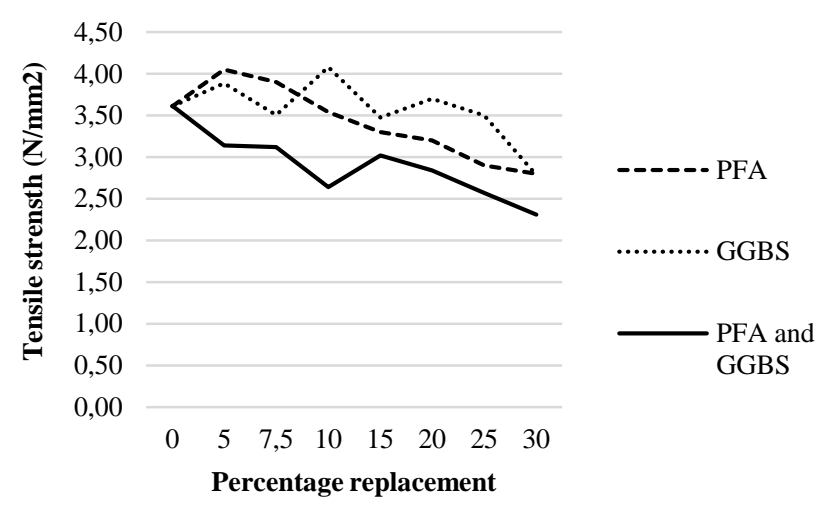

Fig. 7. Tensile strengths of binary and ternary PFA and GGBS-replaced specimens at 91 days against percentage replacements $\left(\mathrm{N} / \mathrm{mm}^{2}\right)$

\section{E. Gain in compressive strength}

Table IX and Fig. 8 show the percentage increase in compressive strengths of the binary and ternary PFA and GGBS-replaced specimens. The gain in strength of the ternary specimens was higher than that of both the PFA and GGBS-replaced specimens up to the $7.5 \%$ replacement, but reduced with further replacement to fall below the control and binary specimens at the $25 \%$ and $30 \%$ replacements.

TABLE IX. PERCENTAGE INCREASE IN COMPRESSIVE STRENGTHS OF BINARY AND TERNARY PFA AND GGBS-REPLACED SPECIMENS BETWEEN 28 AND 91 DAYS

\begin{tabular}{lcccccccc}
\hline \hline & \multicolumn{7}{c}{ Percentage increase in compressive strength } \\
\cline { 2 - 9 } & $0 \%$ & $5 \%$ & $7.5 \%$ & $10 \%$ & $15 \%$ & $20 \%$ & $25 \%$ & $30 \%$ \\
\hline PFA & 15.7 & 16 & 18.6 & 19.5 & 25.4 & 26.6 & 32.7 & 24.7 \\
\hline GGBS & 15.7 & 16.4 & 29.1 & 30.9 & 33.8 & 31.3 & 32.0 & 19.2 \\
\hline Ternary & 15.7 & 20.1 & 33.1 & 28.3 & 21.8 & 17.9 & 15.1 & 14.3 \\
\hline \hline
\end{tabular}

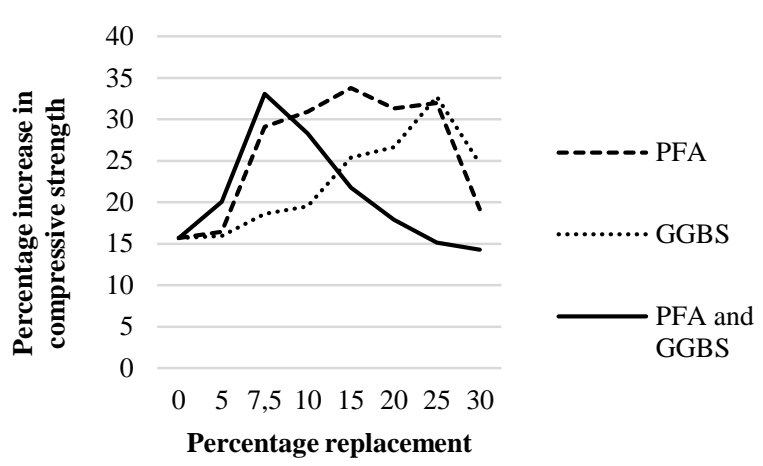

Fig. 8. Percentage increase in compressive strengths of binary and ternary PFA and GGBS-replaced specimens between 28 and 91 days against percentage replacement

\section{CONCLUSION}

This work investigated the performance of Pulverised Fuel Ash (PFA) and Ground Granulated Blast Furnace Slag (GGBS) in ternary concrete. The conclusion that these materials could be used in ternary concrete with an advantage were drawn based on the following findings;

1. Densities of the ternary specimens were lower than those of PFA at all replacements and lower than GGBS specimens for up to the $20 \%$ replacement. Densities of the ternary specimens remained below those of the $0 \%$ replacement.

2. The complementary effect of using the ternary specimens was observed by PFA increasing the workability of GGBS and GGBS improving the compressive strengths of PFA,

3. Gains in compressive strengths of the ternary specimens over time were higher than those of individual binary specimens at lower replacements, even though they reduced with further replacement.

\section{REFERENCES}

[1] E. J. O'Brien, A. S. Dixon, and E. Sheils, Reinforced and Prestressed Concrete Design to EC2: The Complete Process: Spon Press, 2012.

[2] X. M. Zhou, J. R. Slater, S. E. Wavell, and O. Oladiran, "Effects of PFA and GGBS on Early-Ages Engineering Properties of Portland Cement Systems," Journal of Advanced Concrete Technology, vol. 10, pp. 74-85, 2012.

[3] M. Islam and M. Islam, "Strength and durability characteristics of concrete made with fly-ash blended cement," Australian Journal of Structural Engineering, vol. 14, 2013.

[4] M. E. Johnson and A. Gonzalez, "Estimating Cost Savings for Aviation Fuel and CO 2 Emission Reductions Strategies," Collegiate Aviation Review, vol. 31, 2013.

[5] J. D. Bapat, Mineral admixtures in cement and concrete: CRC Press, 2012.

[6] British Standards Institution, "BS EN 197-1:2000. Part 1. Cement composition, specifications and conformity criteria for common 
cements. British Standards Institution (BSI), London, UK," in BSOL, ed, 2000.

[7] C. L. Page and M. M. Page, Durability of concrete and cement composites: Elsevier, Woodhead publishing. ISBN 9781855739406 , 2007.

[8] O. H. Mohammed, R. B. Hamid, and M. R. Taha, "A Review of Sustainable Supplementary Cementitious Materials as an Alternative to All-Portland Cement Mortar and Concrete," Australian Journal of Basic \& Applied Sciences, vol. 6, 2012.

[9] American Society for Testing and Materials, "ASTM C618. Standard specification for coal fly ash and raw or calcined naturalpozzolan for use in concrete, American Society for Testing and Materials, ASTM International, West Conshohocken, PA, 2012, DOI: 10.1520/C0618$12, "$ ed, 2012.

[10] S. H. Sathawane, V. S. Vairagade, and K. S. Kene, "Combine effect of rice husk ash and fly ash on concrete by $30 \%$ cement replacement," Procedia Engineering, vol. 51, pp. 35-44, 2013.

[11] M. Nehdi, M. Pardhan, and S. Koshowski, "Durability of selfconsolidating concrete incorporating high-volume replacement composite cements," Cement and Concrete Research, vol. 34, pp. 2103 2112, 2004.

[12] CarbonBrief. (2016, 22.4.2016). Analysis: UK emissions fall again after record drop in coal use in 2015. Available: http://www.carbonbrief.org/analysis-uk-emissions-fall-again-afterrecord-drop-in-coal-use-in-2015

[13] D. Adesanya and A. Raheem, "A study of the permeability and acid attack of corn cob ash blended cements," Construction and Building Materials, vol. 24, pp. 403-409, 2010.

[14] American Society for Testing and Materials, "ASTM C192/C192M. Standard Practice for Making and Curing Concrete Test Specimens in the Laboratory. 16a, 100 Barr Harbor Drive, PO Box C700, West Conshohocken, PA 19428-2959. United States," ed, 2016.

[15] F. A. Oluokun, "Fly ash concrete mix design and the water-cement ratio law," Materials Journal, vol. 91, pp. 362-371, 1994.

[16] S. Singh, P. Munjal, and N. Thammishetti, "Role of water/cement ratio on strength development of cement mortar," Journal of Building Engineering, vol. 4, pp. 94-100, 2015

[17] British Standards Institution, "BS EN 12350-2:2002. Testing fresh concrete Part 2: Slump-test. BSI, London, UK," ed, 2009.

[18] British Standards Institution, "BS EN 12390-1:2012. Testing hardened concrete. Part 1: Shape, dimensions and other requirements for specimens and moulds. BSI, London, UK," ed, 2012.

[19] British Standards Institution, "BS EN 12390-2:2009. Making and curing specimens for strength tests. BSI, London, UK," ed, 2009.

[20] British Standards Institution, "BS 3762-4.2:1986 ISO 697:1981. Analysis of formulated detergents — Part 4: Physical test methods Section 4.2 Method for determination of apparent bulk density. BSI, London, UK," in BSOL, ed, 1999.

[21] British Standards Institution, "BS EN 12390-3:2009. Testing of Hardened Concrete, Part 3: Compressive strength of test specimens. BSI, London, UK," ed, 2011.

[22] British Standards Institution, "BS EN 12390-6:2009. Testing hardened concrete Part 6: Tensile splitting strength of test specimens. BSI, London, UK," ed, 2010.
[23] British Standards Institution, "BS EN 206:2013. ConcreteSpecification, performance, production and conformity. BSI, London, UK," in BSI Standards Publication, ed, 2013.

[24] C. Arya, Design of structural elements: concrete, steelwork, masonry and timber designs to British standards and Eurocodes. Spon Press, London and New York: Taylor \& Francis, 2009.

[25] British Standards Institution, "BS EN 1992-1-1:2000. Eurocode 2: Design of Concrete Structures, Part 1-1: General Rules and Rules for Buildings. BSI, London, UK," ed, 2004.

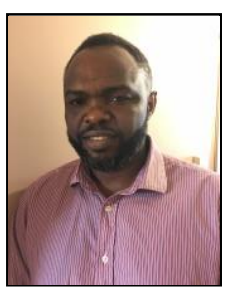

J. Kamau, the main author was born in Kenya. He graduated with a Bachelor of Science with honors degree in civil engineering from Leeds Beckett University, Leeds, West Yorkshire, United Kingdom (UK) in 2010 and a Master of Science degree in structural engineering from the University of Leeds, Leeds, West Yorkshire, UK in 2011. He is currently undertaking a research programme on supplementary cementitious materials at the Leeds Beckett University, Leeds,

West Yorkshire, UK.

He has worked in the past as a CIVIL ENGINEER and is currently working as a STRUCTURAL ENGINEER in Barnsley, South Yorkshire, UK. His publications include "VIABILITY OF USING CORNCOB ASH AS A POZZOLAN IN CONCRETE (2016) -ijset, "PROPERTIES OF CONVENTIONAL CEMENT AND THIN LAYER MORTARS (2016)ijeset and "Suitability of Corncob Ash as a Supplementary Cementitious Material (2016) - ijmse. His research interests are in the sustainability of construction materials.

Mr. Kamau is a Graduate Member of the Institution of Civil Engineers (GMICE)

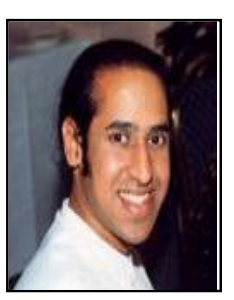

A. Ahmed, was born in Manchester, UK. He graduated with a Bachelor of Science with honors degree in Materials Science from Manchester University, United Kingdom (UK) and a Master of Philosophy degree in Metallurgy from the University of Manchester, UK. He then completed his PhD in Polymer Science from Heriot-Watt University, Edinburgh, UK.

He has been a Senior Lecturer at Leeds Beckett University since 2005, teaching modules in materials science at undergraduate and postgraduate levels. Previously Head of Civil Engineering. His publications "VIABILITY OF USING CORNCOB ASH AS A POZZOLAN IN CONCRETE (2016) -ijset, "PROPERTIES OF CONVENTIONAL CEMENT AND THIN LAYER MORTARS (2016)-ijeset and "Suitability of Corncob Ash as a Supplementary Cementitious Material (2016) - ijmse. His area of research is in the field of sustainable construction materials using recycled and waste products. 